\author{
ZoFia KulińsKa \\ Uniwersytet Mikołaja Kopernika w Toruniu \\ Instytut Języka Polskiego
}

\title{
Presupozycje w perspektywie logicznej
}

Słowa klucze: presupozycje; logika; filozofia języka; Frege; Strawson; Russell

Ke y w ord s: presupposition; logic; philosophy of language; Frege; Strawson; Russell

\section{Wprowadzenie}

Celem niniejszego artykułu jest przypomnienie pewnego wycinka stanu badań (powadzonych wyłącznie z perspektywy logicznej) nad zjawiskiem presupozycji, które intryguje filozofów i językoznawców od przeszło wieku i przez ten czas stało się przedmiotem bardzo wielu logicznych i lingwistycznych analiz. Postaram się przypomnieć trzy klasyczne ujęcia presupozycji autorstwa G. Fregego, B. Russella i P. Strawsona, ponieważ stały się one (zwłaszcza koncepcja Strawsona) punktem wyjścia dla późniejszych rozważań o charakterze językoznawczym, które doprowadziły do sformułowania dwóch niezwykle interesujących teorii dotyczących presupozycji, mianowicie teorii presupozycji semantycznych oraz teorii presupozycji pragmatycznych. 


\section{Gottloba Fregego koncepcja presupozycji}

Frege był pierwszym filozofem, który zauważył zjawisko presupozycji, lecz nie nadał mu jeszcze żadnej konkretnej nazwy ${ }^{1}$. Kwestię tę porusza on pośrednio w swych rozważaniach dotyczących natury odniesienia i wyrażeń referencjalnych. Tego typu zagadnienia zajmują centralne miejsce w jego teorii logicznej i związane są z jednym z zasadniczych pytań filozofii Fregego, mianowicie z pytaniem o to, jak wyrażenia języka naturalnego mające funkcję referencji powinno się tłumaczyć na ścisłe języki logiczne.

Dyskusja na temat presupozycji, w której jako pierwszy głos zabrał właśnie Frege, daleka była od logicznej precyzji, pełna zaś niejasności i niedopowiedzeń, które nastręczały wiele wątpliwości ówczesnym i późniejszym interpretatorom. I choć rekonstrukcja poglądów Fregego ma wciąż charakter dyskusyjny, z pewnością podniósł on kilka bardzo ważnych kwestii, które stały się później kluczowe dla rozważań nad pojęciem presupozycji. W Sensie i nominacie, najważniejszym bodaj swoim tekście, rozważa on zdanie:

\section{Kepler umart w nędzy.}

Jak zauważa na wstępie: „Ilekroć się coś stwierdza, tylekroć z góry przyjmuje się założenie [Voraussetzung], iż użyte imiona własne, proste czy złożone, mają nominaty. Tak więc, jeżeli stwierdzamy: Kepler umart w nędzy, to zakładamy, że nazwisko Kepler kogoś lub coś desygnuje" (Frege 1967: 240). Następnie stwierdza jednak, że sformułowanie Kepler kogoś lub coś desygnuje bez wątpienia nie należy do znaczenia zdania Kepler umart w nę$d z y$. Gdybyśmy bowiem założyli, że powyższe stwierdzenie stanowi element znaczenia zdania 1., wówczas zdanie to miałoby następującą formę logiczną:

2. Kepler umart w nędzy i Kepler kogoś lub coś desygnuje.

A więc znaczyłoby to, zgodnie z I prawem De Morgana, że zdanie Kepler nie umart $w$ nędzy byłoby równoważne alternatywie:

1 Termin ,presupozycja” został wprowadzony do obiegu naukowego przez Strawsona. Pierwszy raz pojawił się w jego rozprawie O odnoszeniu się użycia wyrażeń do przedmiotów z 1950 roku. 


\section{Kepler nie umart w nędzy lub nazwa Kepler nie ma odniesienia.}

Powyższa alternatywa jest jednak, zdaniem Fregego, absurdem, gdyż co do istnienia desygnatu nazwy Kepler nie możemy mieć wątpliwości. Dodaje więc: „To, że nazwisko Kepler kogoś lub coś desygnuje, jest właściwie założeniem zarówno twierdzenia Kepler umart w nędzy, jak i jego negacji” (Frege 1967: 240).

Wątpliwości nasuwają również pewne określenia czasowe. Frege jako pierwszy zauważył ich specyficzne własności i skojarzył je z problemami sygnalizowanymi powyżej: „Po tym jak Szlezwik Holsztyn zostat oderwany od Danii, Prusy i Austria poróżnity się ze sobq (...). W tym sformułowaniu jest wystarczająco jasne, że nie powinniśmy go traktować jako części tego sensu, iż Szlezwik Holsztyn kiedyś został oderwany od Danii, lecz raczej, że jest to założenie konieczne dla samego istnienia nominatu wyrażenia po oderwaniu Szlezwiku Holsztynu od Danii" (Frege 1967: 243).

Owo „założenie konieczne dla samego istnienia nominatu (desygnatu)” danego wyrażenia zawierającego określenie czasowe, to właśnie presupozycja taka, jak ją będzie później rozumiał Strwason, a więc pewien sąd należący do innego poziomu niż semantyczny, którego prawdziwość umożliwia przypisanie danemu zdaniu wartości logicznej. A zatem w sytuacji, gdy presupozycja zdania nie jest spełniona, nie ma ono wartości logicznej. To zapewne miał na myśli Frege kontynuując swoje rozważania - cudzoziemiec, który nie zna historii konfliktu prusko-austriackiego, „owo zdanie (...) uważać będzie za ani prawdziwe, ani fałszywe. Odmówi mu chyba w ogóle nominatu, ponieważ zdanie zależne nie miałoby nominatu. Owo zdanie zależne - jedynie pozornie podaje determinację czasową" (Frege 1967: 243).

Teoria presupozycji Fregego jest jednak o wiele mniej spójna niż mogłoby się wydawać. Co do pewnych kwestii, takich jak na przykład status wyrażeń posiadających presupozycje, sam Frege miał zdaje się do końca sporo wątpliwości i tym samym pozostawił je nierozstrzygnięte. Stwierdzał, przykładowo, w pewnych miejscach, że presupozycje mają użycia zdań (stwierdzenia), w innych zaś, że mająje same zdania, a w jeszcze innych, że to sami nadawcy wypowiedzi podtrzymuja pewne presupozycje (Levinson 2010: 197): „,gdy mówimy księżyc (...) zakładamy tu nominat" (Frege 1967: 231).

Mimo tego typu niejasności, których u Fregego nie brakuje, pewne twierdzenia na temat presupozycji głosił, jak się wydaje, bardzo konsekwentnie. 
Można do nich zaliczyć przekonanie, że zwroty mające funkcję odniesienia, jak również (przykładowo) określenia czasowe, zawierają presupozycję, że się do czegoś rzeczywiście odnoszą (posiadają desygnat). Ponadto Frege dostrzegł kluczową, jak się później okazało, własność presupozycji, mianowicie niezmienność względem negacji, czyli tożsamość zbioru presupozycji zarówno zdania, jak i jego zaprzeczenia. Zauważył także, że aby stwierdzeniu (jak wspomina w przykładzie z Keplerem) lub zdaniu (jak powiada przy okazji rozważań nad problemem określeń czasowych) można było przypisać wartość logiczną, jego presupozycje muszą być prawdziwe lub - inaczej mówiąc - spełnione.

Z czasem stało się jasne, że problemy, których Frege nie potrafił rozstrzygnać lub które może nawet nie do końca dostrzegał, miały istotne znaczenie dla badań nad zjawiskiem presupozycji. Niemniej jednak, to właśnie jemu zawdzięczamy sformułowanie pytań, wokół których koncentrowała się większość późniejszych dyskusji na temat tego, czym jest presupozycja i jakie są jej własności.

\section{Bertranda Russella koncepcja presupozycji}

Wykładając w artykule pt. „On denoting” swoją kluczową teorię deskrypcji, Russell twierdził, że rozwiązania Fregego są po prostu błędne (Russel 1905: 479-493). Choć obaj zmagali się z tymi samymi problemami z zakresu teorii odniesienia, każdy z nich doszedł do całkowicie odmiennych wniosków.

Russell stawia sprawę w ten sposób: poprawność analizy danej wypowiedzi sprowadza się do tego, że ustali się znaczenie każdego słowa w zdaniu, w którym dokonana jest ta wypowiedź. Każde bowiem słowo w zdaniu musi mieć ustalone i niezmienne znaczenie. Stwierdza następnie, że znaczenia słowa należy upatrywać w tym, że zastępuje ono pewien przedmiot ${ }^{2}$. Tego typu słowa, odnoszące się do określonych obiektów, oznaczane są jako nazwy. Ich cechą charakterystyczną jest więc to, że zastępują dany przedmiot poprzez jego oznaczanie. Możemy uogólnić powyższe rozważania stwierdzając, że zdaniem Russella każde słowo sensownego zdania posiada znaczenie.

Tego rodzaju konstatacja rodzi jednak cały szereg kolejnych problemów. Jakim bowiem sposobem zapewnić wspomniane odniesienie każdemu

\footnotetext{
2 A więc podobnie jak u Fregego.
} 
wyrażeniu zdania. Łatwo można zauważyć, że o ile ustalenie odniesienia w stosunku do nazw nie powinno sprawiać większych trudności, o tyle znalezienie „desygnatu” pojęć takich, jak np. „kochać” jest co najmniej kłopotliwe. Na tym jednak nie koniec. Problemy mnożą się, gdy weźmiemy pod uwagę takie zdania, jak te, w których zaprzecza się wypowiedź o istnieniu lub orzeka się coś o nieistniejących osobach ${ }^{3}$. Russell postawił sobie wobec tego za cel wyjaśnienie, jak możliwe jest sensowne zanegowanie istnienia czegoś oraz mówienie o czymś, co nie istnieje.

Russell (1967: 260) przeprowadza analizę następującego zdania:

\section{Obecny król Francji jest tysy.}

Frege zapewne rozwiązałby powyższy problem, odwołując się do swojego rozróżnienia na sens i znaczenie. Stwierdziłby przeto, że zdanie takie zachowuje swój sens (czyli znaczenie w dzisiejszym rozumieniu), nawet jeśli, jak to jest $\mathrm{w}$ istocie, nie posiada znaczenia (odniesienia). W związku z tym, wypowiedź tę uznałby Frege za ani prawdziwą, ani fałszywą, lecz po prostu pozbawioną wartości logicznej. Russell zauważył jednak, że rozwiązanie, jakiego chciałby Frege, prowadzi do poważnych anomalii i zaproponował zamiast tego swoją słynną teorię deskrypcji, która zdominowała badania nad teorią odniesienia na blisko 50 lat. Teoria ta koncentrowała się przede wszystkim na problemie odniesienia zwrotów denotujących. Zwrotem denotujacym ${ }^{4}$ nazywał Russsell "taki zwrot, jak każdy z poniższych: a man, some man, any man, all men, the present King of England, the present King of France, the centre of mass of the Solar System at the first instant of the twentieth centu$r y$, the revolution of the sun round the earth. A więc zwrot jest zwrotem denotującym wyłącznie na mocy swej formy. Możemy wyróżnić trzy wypadki: 1. Zwrot może być zwrotem denotującym, a mimo to niczego nie denotować, np. the present King of France [tylko ten wypadek będzie interesujący ze względu na problem presupozycji]. 2. Zwrot może denotować jeden określony obiekt, np. the present King of England denotuje pewnego mężczyznę. 3. Zwrot może denotować w sposób niejasny, np. a man denotuje nie - wielu ludzi, lecz jakiegoś nieokreślonego człowieka” (Russell 1967: 253).

${ }^{3}$ Chodzi tu tzw. zdania z pustym podmiotem.

${ }^{4}$ Deskrypcja określona to w tłumaczeniu J. Pelca zwrot denotujacy (por. Russell 1967). 
Russell utrzymywał, że zwroty denotujące, a więc te o postaci ten jedyny $x$, taki-a-taki $x$, nie dają się w prosty sposób przełożyć logicznie na zwroty, których moglibyśmy się tu spodziewać. W sytuacji, gdy pojawiają się one w funkcji podmiotu w zdaniu języka naturalnego (jak np. w zdaniu 4.), na poziomie formy logicznej nie mają one charakteru podmiotów logicznych, lecz stanowią wyraz koniunkcji pewnych sądów. A zatem, jak sądził Russell, zdania:

5. (ten jedyny) $F$ jest $G$.

nie wolno nam przełożyć na prostą formułę podmiotowo-orzecznikową o postaci:

6. G (ten jedyny F).

Powinniśmy zaś przełożyć to zdanie na koniunkcję trzech sądów:

7. Istnieje pewien przedmiot $x$ taki, że:

a) ma on wtasność $F$;

b) nie ma różnego od niego przedmiotu y, który ma własność F;

c) ma on własność $G$.

Wracając zatem do przykładu z królem Francji, jego logiczną formą nie będzie zdanie:

8. Łysy ((ten jedyny) król Francji).,

ale bardziej złożona konstrukcja:

9. $\exists x(\operatorname{Król}(x) \wedge \sim \exists y((y \neq x) \wedge \operatorname{Król}(y)) \wedge \notin y s y(x))$,

którą da się sparafrazować jako: Istnieje król Francji i nie ma nikogo innego, kto byłby królem Francji, a ponadto jest on tysy.

Russellowi udało się udowodnić, że dzięki jego analizie możliwe jest rozwiązanie problemów, które pojawiają się w wypadku przyjęcia innych poglądów. Dla przykładu, analiza ta rozwiązuje kwestię sensowności zdań, 
których podmiot do niczego się nie odnosi. Zdania takie (jak np. 4.) są wedle rozwiązań zastosowanych w teorii Russella sensowne, gdyż są po prostu fałszywe. Na gruncie jego analiz, sformułowania typu (ten jedyny) król Francji, a więc deskrypcje określone, stanowią jednocześnie stwierdzenie istnienia odpowiedniej osoby (na mocy 7.) Można przypuszczać, że Russell zgodziłby się, że owo stwierdzenie istnienia ma charakter presupozycji, która jednak, inaczej niż u Fregego, znajduje się tu na poziomie semantycznym zdania, jest częścią jego znaczenia.

Jedną z niewątpliwych korzyści, jakie dostrzegał Russell w swojej teorii, było dopuszczenie tego, co dziś nazywamy wieloznacznościami wynikłymi z zasięgu (Levinson 2010: 198). A więc zdanie przeczące:

10. Obecny król Francji nie jest łysy.

można interpretować dwojako. Po pierwsze możemy przyjąć, że owszem istnieje król Francji, przy czym stwierdza się tylko tyle, że nie jest on łysy. Drugi, mniej powszechny i chyba też mniej naturalny sposób odczytania powyższego zdania polegałby na zaprzeczeniu, że jest zarazem prawdą, że istnieje ktoś taki, jak obecny król Francji oraz że jest on łysy. Gdyby nie ta możliwość podwójnej interpretacji, zdanie typu:

11. Obecny król Francji nie jest tysy, dlatego, że osoba taka nie istnieje.

nastręczałoby wiele trudności. Dla Russella tego rodzaju zdania z odwołaną presupozycją można interpretować jedynie w wersji drugiej (szeroko) i to rozwiązuje problem.

W Russellowskiej formule (9.) mamy co najmniej dwa miejsca, w których przyłożyć możemy negację. Dzięki temu możliwe staje się uchwycenie wieloznaczności. Negacja może bowiem wystąpić w zasięgu szerokim:

12. $\sim(\exists x(\operatorname{Król}(x) \wedge \sim \exists y((y \neq x) \wedge \operatorname{Król}(y)) \wedge \notin y s y(x)))$,

co można sparafrazować jako: Nie jest prawda, że: (a) istnieje król Francji $i$ (b) nie ma nikogo innego, kto byłby królem Francji i (c) jest on łysy. Jej zakres może być jednak także wąski: 


\section{3. $\exists x(\operatorname{Król}(x) \wedge \sim \exists y((y \neq x) \wedge \operatorname{Król}(y)) \wedge \sim \notin y s y(x))$,}

co z kolei można wyrazić innymi słowy jako Istnieje król Francji i nie ma nikogo innego, kto byłby królem Francji, a ponadto król Francji nie jest tysy.

Forma negacyjna z szerokim zasięgiem pozwala, aby zdanie 11. było zaprzeczeniem samego istnienia króla Francji, podczas gdy forma z zasięgiem wąskim umożliwia zaprzeczenie jednie faktu, że do króla Francji stosuje się pewien predykat.

Teoria deskrypcji Russella została powszechnie przyjęta i nie natrafiła na poważniejszą opozycję do czasu, gdy pewien niezbyt jeszcze znany brytyjski filozof, późniejszy profesor oksfordzki, zaproponował nieco inne podejście do problemu.

\section{Petera Strawsona koncepcja presupozycji}

W swoim tekście pt. „O odnoszeniu się użycia wyrażeń do przedmiotów” Strawson (1967) zaproponował autorską wizję rozwiązania problemów, z którymi borykał się Russell w „On denoting”. Uznał on, że gros teoretycznych kłopotów bierze się z tego, że badacze nie dostrzegają różnic między zdaniami a zdaniami użytymi do tego, żeby coś stwierdzić (np. stwierdzić prawdziwość lub fałszywość danego sądu). To właśnie za sprawą pomieszania tych dwóch poziomów Russell uznał, że jeśli zdanie:

\section{Obecny król Francji jest tysy.}

można uznać za sensowne i przyznać, że ma ono wyraźne znaczenie, to siła rzeczy, musi ono być prawdziwe lub fałszywe. Strawson jednak, podążając drogą swego rozróżnienia na zdania i stwierdzenia, oponuje wobec rozwiązania Russela i zauważa, że zdania nie są prawdziwe ani fałszywe, taką własność mają jedynie stwierdzenia. A zatem prawdziwość stwierdzenia 4. zależy wyłącznie od historycznego kontekstu. I tak stwierdzenie to mogłoby być wygłoszone jako prawdziwe w roku 1315 (czyli za panowania Karola IV Pięknego, zwanego także Karolem I Łysym), fałszywe w roku 1717 (na tronie zasiadał wówczas siedmioletni Ludwik XVI Ukochany), a w roku 2015 o stwierdzeniu tym nie możemy sensownie powiedzieć, że jest prawdziwe 
lub fałszywe, skoro dziś ktoś taki, jak król Francji nie istnieje, pytanie dotyczące prawdziwości lub fałszywości tego stwierdzenia w ogóle nie powstaje.

Strawson zauważył pewną szczególną relację, która łączy następujące zdania:

4. Obecny król Francji jest tysy.

14. Istnieje obecny król Francji.

Związek ów polega na tym, że stwierdzenie 14. stanowi wstępny warunek tego, by stwierdzeniu 4. można było w ogóle przypisać wartość logiczną. Zjawisko to nazwał on presupozycją i twierdził, że można je uznać za szczególny rodzaj wnioskowania pragmatycznego ${ }^{5}$. Tego typu wnioskowanie różni się znacząco od wynikania w sensie logicznym i opiera się na konwencjach związanych z użyciem wyrażeń, które mają funkcje referencji. Strawson doszedł jednak do wniosku, że owe konwencje są czymś o wiele bardziej złożonym, niż to, co daje się uchwycić przy pomocy ,prostej analizy egzystencjalnej" ${ }^{\text {" }}$ Tworzą one skomplikowaną sieć wzajemnych powiązań wraz z innymi konwencjami określającymi, co to znaczy coś stwierdzić lub wygłosić z asercją. Bardziej sformalizowana definicja presupozycji według Strawsona brzmi następująco: stwierdzenie A presuponuje stwierdzenie B wtedy i tylko wtedy, gdy B jest warunkiem koniecznym prawdziwości lub fatszywości A.

Istnieje jednak wiele niepożądanych skutków propozycji Strawsona wobec rozwiązań zaproponowanych przez Russella, których skądinąd ten pierwszy nie próbuje nawet wyjaśniać. Jednym z nich jest fakt, że odrzucenie złożonej formy logicznej zdań z deskrypcjami uniemożliwia Strawsonowi wyjaśnienie zdań przeczących w rodzaju:

11. Obecny król Francji nie jest tysy, dlatego że osoba taka nie istnieje.,

gdzie odwołuje się samą presupozycję. Dzieje się tak dlatego, że na gruncie teorii Strawsona (a także Fregego) presupozycje mają tę własność, że dowolne, wygłoszone w pewnych okolicznościach zdanie przeczące będzie zachowywało presupozycje zdania zaprzeczanego. Napotykając ten sam problem,

\footnotetext{
5 Tak byśmy to dziś nazwali.

6 Tak określił teorię Russella Strawson.
} 
Russell mógł zawsze wskazać na występowanie dwóch różnych rodzajów zasięgu negacji, które stały się dopuszczalne dzięki zastosowaniu złożonych form logicznych. Gdyby Strawson zauważył ten kłopot, utrzymywałby zapewne, że to samo słowo „nie” jest wieloznaczne. W jednym ze swych znaczeń zachowuje presupozycje, w drugim zaś obejmuje je, umożliwiając tym samym ich zaprzeczenie. Sam Strawson wypowiedział się w tej kwestii, uznając, że jedynym możliwym odczytaniem stwierdzenia:

10. Obecny król Francji nie jest tysy.

jest:

13. Istnieje król Francji i nie ma nikogo innego, kto byłby królem Francji, a ponadto król Francji nie jest tysy.,

a więc stwierdzenie, w którym zaprzecza się wyłącznie predykatowi. Nie zmienia to oczywiście faktu, że problem zaprzeczenia presupozycji Strawson pozostawił bez wyjaśnienia.

\section{Podsumowanie}

Na podstawie powyższych rozważań można zauważyć, że w połowie XX wieku stanowiska uczonych odnośnie do problemu presupozycji były podzielone. Frege i Strawson, a także, rzecz jasna, ich zwolennicy oraz kontynuatorzy, bronili podobnego przekonania i zdecydowanie oponowali przeciw analizie deskrypcji określonych Russella. Zaletą ich sposobu widzenia spra$w^{7}$ jest oczywiście przede wszystkim to, że wydają się bardziej odpowiadać naszym bezpośrednim intuicjom językowym. Ta też intuicja podpowiada nam, że jeśli, przykładowo, wygłaszamy w jakichś okolicznościach zdanie 4., to treścią, którą przede wszystkim chcemy wyrazić, jest to, że pewna określona osoba jest łysa, a sugestia, że osoba ta istnieje, stanowi coś na kształt przyjętego w tle założenia, w świetle którego stwierdzenie to nabiera sensu. Bez wątpienia na gruncie teorii Russella nie da się wyjaśnić tego faktu.

${ }^{7}$ Dziś znanego pod nazwą teorii presupozycyjnych. 
Dzięki analizie deskrypcji określonych Russella możliwe było jednak poradzenie sobie z problemem tzw. zdań z odwołaną presupozycją, jak np. 13., o czym była już wcześniej mowa. Niewątpliwą zasługą Russella było także zwrócenie uwagi na istnienie dwóch różnych rodzajów zasięgu negacji, a także na powstające w konsekwencji tego wieloznaczności.

Do momentu zatem, gdy pojęcie presupozycji znalazło się w polu zainteresowania językoznawców (a więc właściwie do końcówki lat 70.), w literaturze filozoficznej dogłębnie poznano już problem, zwrócono uwagę na wiele istotnych rozróżnień, stworzono kilka alternatywnych teorii. Najważniejsze z nich to (Levinson 2010: 201): dostrzeżenie opozycji: wynikanie logiczne i presupozycja, przeprowadzenie rozróżnienia między stwierdzaniem czegoś a presupozycją, zauważenie problemu z określeniem statusu presupozycji czy jest to relacja między zdaniami (jak czasami sugerował Frege), stwierdzeniami (jak utrzymywał Strawson), czy może nadawcami a przyjętymi założeniami (jak w innych miejscach twierdził Frege), poruszenie problemu dwuznaczności negacji, która w niektórych przypadkach obejmuje presupozycję, a w innych nie - czy mianowicie tę wieloznaczność należy traktować jako różnicę zasięgu, czy raczej polisemię leksykalną, uznanie, że coś, co wydaje się swego rodzaju przyjętym w tle założeniem (presupozycją), może tak naprawdę należeć do poziomu semantycznego, czyli może być stwierdzane, czy też logicznie implikowane na równi z całą resztą znaczenia zdania.

\section{Bibliografia}

Frege G., 1967, Sens i nominat, tłum. J. Pelc, w: J. Pelc (red.), Logika i język. Studia z semiotyki logicznej, Warszawa: Państwowe Wydawnictwo Naukowe, s. 225-251.

Levinson S.C., 2010, Pragmatyka, Warszawa: Wydawnictwo Naukowe PWN.

Russell B., 1905, On Denoting, Mind, New Series, Vol. 14, No 56, pp. 479-493.

Russell B., 1967, Denotowanie, tłum. J. Pelc, w: J. Pelc (red.), Logika $i$ język. Studia z semiotyki logicznej, Warszawa: Państwowe Wydawnictwo Naukowe, s. 253-275 .

Strawson P., 1967, O odnoszeniu się użycia wyrażeń do przedmiotów, tłum. J. Pelc, w: J. Pelc (red.), Logika i język. Studia z semiotyki logicznej, Warszawa: Państwowe Wydawnictwo Naukowe, s. 377-413. 


\section{Presupposition from a logical perspective}

\section{( s u m mary)}

The main aim of this article is to show the problem of presupposition from the side of the logical analysis of language. Deliberations on the topic derive from the nineteenth century and are connected to Gottlob Frege. In his work titled "On sense and reference", he asks how the expressions with a referring function should be translated into logical language. He also emphasizes "assumptions for the existence of referent (designation)", whose characteristic feature is that their authenticity is a crucial condition to provide a sentence with a logical meaning. Therefore, Frege highlighted the crucial feature of presupposition that is constancy under negation. However, Frege's concept lacks unity when it comes to the level of the language on which the assumptions should be made. An opposing view on presupposition is presented by Russell and his idea of definite descriptions, which solves the problem of sentences with non-existent subject terms, of which Frege's language philosophy does not provide a precise explanation. Russell claims that denoting phrases can be expressed in the form of conjunction of the value of the sentence and thus sentences predicating on something that does not exist happen to be false. However, Russel's view differs from the one presented by a twentieth-century philosopher, Peter Strawson. The latter maintains that the problems mentioned derive from the fact that scholars do not notice the difference between sentences and sentences used to have an assertive meaning and, consequently, that the sentences cannot be true or false since this is a characteristic feature of statements. He also emphasizes a connection between them, in which one statement is a primary condition to give a logical value to another statement. Strawson called the phenomenon a presupposition and claimed that it can be recognized as a specific kind of pragmatic deduction/presupposition. The article focuses on showing the three views on presupposition on the grounds of the philosophies of language presented by scholars mentioned above. 